\title{
Evaluation of Silkworm Lines against Variations in Temperature and RH for Various Parameters of Commercial Cocoon Production
}

\author{
Mubashar Hussain, ${ }^{1}$ Shakil Ahmad Khan, ${ }^{2}$ Muhammad Naeem, ${ }^{1}$ Tahir Aqil, ${ }^{3}$ \\ Rizwan Khursheed, ${ }^{2}$ and Ata ul Mohsin ${ }^{1}$ \\ ${ }^{1}$ Pir Mehr Ali Shah Arid Agriculture University, Rawalpindi 46000, Pakistan \\ ${ }^{2}$ Sericulture Research Laboratory, 54000 Lahore, Pakistan \\ ${ }^{3}$ University of Gujrat, 50700 Gujrat, Pakistan
}

Correspondence should be addressed to Mubashar Hussain, mubashir_g@hotmail.com

Received 20 May 2011; Accepted 4 July 2011

Academic Editor: G. B. Dunphy

Copyright (c) 2011 Mubashar Hussain et al. This is an open access article distributed under the Creative Commons Attribution License, which permits unrestricted use, distribution, and reproduction in any medium, provided the original work is properly cited.

Eleven inbred silkworm lines (M-101, M-103, M-104, M-107, Pak-1, Pak-3, Pak-2, Pak-4, PFI-1, PFI-2, and S-1) were evaluated for various parameters of cocoon production under different temperature and relative humidity conditions $\left(25 \pm 1,30 \pm 1\right.$, and $35 \pm 1{ }^{\circ} \mathrm{C}$ in combination with 55, 65, and 75\% RH for three hrs during 4th and 5th instar. The experiment was laid out in factorial design with three replications. Significant variations in the performance of silkworm lines were noticed due to influence of temperature and RH treatment on 4th and 5th instar larvae. The silkworm lines performed significantly better when the larvae were reared at $25 \pm 1{ }^{\circ} \mathrm{C}$ with $70-80 \% \mathrm{RH}$ while almost all the silkworm lines showed poor performance at higher temperature exposures for $3 \mathrm{hrs}$. Exposures to lower humidity (55\%) during larval rearing in 4th and 5th instar at different temperatures $(25 \pm 1,30 \pm 1$, and $35 \pm 1{ }^{\circ} \mathrm{C}$ ) resulted in lowering the cocoon production. The cumulative evaluation index values for different traits showed that Pak4 (61.42) was the best line followed by M-101 (59.15), Pak-2 (56.37), Pak-3 (52.83) PFI-I (52.62), and M-107(50.03). The study clearly underlines the importance of optimization of environmental conditions during larval rearing in relation to commercial cocoon production. The investigations strongly recommend that temperature and relative humidity in the range of $25-26^{\circ} \mathrm{C}$ and 70-80\%, respectively, are mandatory for excellent results of cocoon production and Pak-4, M-101, Pak-2, Pak-3, PFI-I, and M-107 were suitable for commercial rearing.

\section{Introduction}

Silkworm is one of the most important animals which produces silk thread in the form of cocoon by consuming mulberry leaves during larval period. The growth and development of silkworm is greatly influenced by environmental conditions [1]. The biological as well as cocoonrelated characters are influenced by ambient temperature, rearing seasons, and genetic constitution of silkworm strains [2]. Different seasons affect the performance of Bombyx mori L. [3]. The seasonal differences in the environmental components considerably affect the genotypic expression in the form of phenotypic output such as cocoon weight, shell weight, and cocoon shell ratio [4]. The variations in the environmental conditions during last decade emphasizes manipulation of the temperature and relative humidity for sustainable cocoon production [5]. Rearing conditions affects growth and development of larvae and cocoon production [6].

Many of the silkworm characters are not only controlled by genes but are also influenced by environmental factors such as temperature and relative humidity. High temperature affects nearly all biological processes including the rates of biochemical and physiological reactions [7, 8] ultimately affecting the quality and quantity of cocoon crops. Several researchers $[1,9]$ reported that the silkworm larvae are 
sensitive to high temperature (above $25 \pm 1^{\circ} \mathrm{C}$ ) during 4th and 5th instars and lower or higher levels of $\mathrm{RH}$ affect the growth and development of silkworm larvae. Some strains of silkworm due to consistent domestication have become highly sensitive to variations in environmental conditions, especially seasonal variations in temperature and humidity in tropical parts of the subcontinent $[5,10]$. Environmental stress during silkworm rearing adversely affects growth and development and impairs the production of good quality silk seed with resistance to diseases and ability to withstand high temperature and humidity [11]. Perusal of literature reveals that little work has been carried out on the effect of temperature and relative humidity fluctuations on the cocoon production of silkworm lines in Pakistan. The present study, therefore, was conducted to find out the effect of variations in temperature and humidity during rearing on silk worm egg production and egg fertility of the silkworm, $B$. mori. The study would be helpful in popularizing sericulture in farming community.

\section{Materials and Methods}

The larvae of eleven silkworm lines (M-101, M-103, M-104, M-107, Pak-1, Pak-2, Pak-3, Pak-4, PFI-I, PFI-II, and S-1) were reared at Sericulture Research Laboratory, Lahore during autumn and spring seasons in 2007-2008. The eggs were incubated at optimum conditions of temperature, relative humidity, and light/darkness ratio (12 hr: $12 \mathrm{hr})$. The eggs were spread on sheets in single layer to ensure uniform conditions for all the eggs and at pin head stage complete darkness was provided (black boxed) to ensure uniform hatching. The rearing rooms and all the appliances were washed, cleaned, and disinfected by using standard methods following [12]. The young larvae (1st to 3rd instars) were reared at $27-28^{\circ} \mathrm{C}$ with 85 to $90 \% \mathrm{RH}$. In each replication, 300 larvae were retained during 1 st to 3 rd instar. The larvae were served with four to five feedings at an interval of 5 hours starting at 0800 PST. At the end of each instar bed cleaning nets were used to pick up the larvae and replace their bed. The larvae were reared under standard rearing conditions [13]. At the beginning of 4 th instar, 50 larvae were counted from each replication and retained for further studies in each replication. The 4 th and 5 th instar larvae were subjected to the following treatments as shown in Table 1.

On 5th day of the 5th instar, ripe larvae were collected manually and transferred to mountages for cocooning. The cocoons were made within $72 \mathrm{hrs}$ of mounting and seed cocoons were harvested on eighth day of spinning. Cocoons were preserved at $25 \pm 1{ }^{\circ} \mathrm{C}$ and $75 \pm 5 \% \mathrm{RH}$. The data on various parameters were collected by following Rao et al. [14].

2.1. Cocoon Weight $(\mathrm{g})$. The average weight $(\mathrm{g})$ of 5 male and 5 female cocoons was taken randomly on 6 th day after onset of spinning from all the replication in a treatment for a given silk worm line.
TABLE 1: Temperature and relative humidity regimes during 4 th and 5 th instar larval rearing of silkworm, Bombyx mori L.

\begin{tabular}{|c|c|c|}
\hline Treatments & Temperature $\left({ }^{\circ} \mathrm{C}\right)$ for $3 \mathrm{hrs}$ & Relative humidity (\%) \\
\hline$T_{0}$ & $\begin{array}{l}\text { Standard rearing temperature } \\
\qquad\left(25 \pm 1^{\circ} \mathrm{C}\right)\end{array}$ & Standard RH (70-80\%) \\
\hline$T_{1}$ & $25 \pm 1$ & 55 \\
\hline$T_{2}$ & $25 \pm 1$ & 65 \\
\hline$T_{3}$ & $25 \pm 1$ & 75 \\
\hline$T_{4}$ & $30 \pm 1$ & 55 \\
\hline$T_{5}$ & $30 \pm 1$ & 65 \\
\hline$T_{6}$ & $30 \pm 1$ & 75 \\
\hline$T_{7}$ & $35 \pm 1$ & 55 \\
\hline$T_{8}$ & $35 \pm 1$ & 65 \\
\hline$T_{9}$ & $35 \pm 1$ & 75 \\
\hline
\end{tabular}

$$
\begin{aligned}
& \text { Cocoon Weight }(\mathrm{g}) \\
& =\frac{\text { Wt. of } 5 \text { male cocoons }(\mathrm{g})+\text { Wt. of } 5 \text { female cocoons }(\mathrm{g})}{10} \\
& \quad \times 100 .
\end{aligned}
$$

2.2. Cocoon Shell Weight $(g)$. The average weight $(\mathrm{g})$ of 5 male and 5 female cocoon shells $(\mathrm{g})$ of the same cocoons after removing pupa was taken randomly for the calculation of cocoon weight from all the replication in a treatment for a given silk worm line

$$
\begin{aligned}
& \text { Shell Weight }(\mathrm{g}) \\
& \qquad \begin{aligned}
= & \frac{\text { Wt. of }(5 \text { male }+5 \text { female }) \text { cocoons }(\mathrm{g}) \text { without pupa }}{10} \\
& \times 100 .
\end{aligned}
\end{aligned}
$$

2.3. Cocoon Shell Ratio (\%). It is the total content of shell available in the cocoons. It is the average ratio of 5 male and 5 female cocoon shells ( $\mathrm{g}$ ) of the same cocoons to the total cocoon weight and assessed in percentage

$$
\text { Cocoon weight }(g)=\frac{\text { Cocoon Shell Weight }}{\text { Cocoon Weight }} \times 100 \text {. }
$$

2.4. Filament Length $(m)$. The length of unwound silk filament from the cocoon was measured by reeling three cocoons from each treatment for each line and the average in meters was taken as the filament length for a given silk worm line

Filament length $(\mathrm{m})$

$$
=\frac{\text { Length of raw silk } \times \text { average number of reeled cocoons }}{\text { Number of reeling cocoons }} .
$$


2.5. Cocoon Yield ( $\mathrm{kg} / 10,000$ Larvae). It is the total weight of live cocoons expressed in kilograms for unit number of larvae retained after 3rd moult. The weight of all live cocoons was divided by total number of live cocoons in all replications to get average weight of cocoon for a given silk worm line

\section{Cocoon Yield}

$$
\begin{aligned}
= & \frac{\text { Average wt. of cocoon }(\mathrm{kg}) \times \text { No. of live cocoons obtained }}{\text { larvae retained after } 3 \text { rd instar }(50)} \\
& \times 100 .
\end{aligned}
$$

2.6. Statistical Analysis. The experiment was laid out in Completely Randomized Design (Factorial) with three replications. Data on various parameters (Cocoon Weight, Shell Weight, Shell Ratio, Cocoon Yield, and Filament Length) studied were analyzed using MSTATC statistical package. Duncan's Multiple Range Test (DMRT) was used for mean comparison. The analysis of the data was carried out to assess the effect of treatments by following Steel and Torrie [15].

2.7. Evaluation Index Method (EI). The performance of inbred silkworm lines was evaluated by Evaluation index value (EI) for silkworm breed performance was calculated by following Mano et al. [16]

$$
\text { Evaluation Index }(\mathrm{EI})=\frac{(A-B)}{C} \times 10+50,
$$

where $A$ is mean value of the trait concerned; $B$ is overall mean of particular trait; $C$ is standard deviation; 50 is constant.

\section{Results and Discussion}

The data collected on various parameters have been analyzed and results have been presented in Figures 1-15.

3.1. Cocoon Weight (g). The data obtained on cocoon weight revealed significant variations among silkworm lines $\left(F_{10}\right.$, $440=11844.85, P<0.05)$, different treatments $\left(F_{9}, 440=\right.$ 2689.55, $P<0.05$ ), and interaction between silkworm lines and treatments $\left(F_{90}, 440=90.586, P<0.05\right)$. The highest cocoon weight $(1.589 \mathrm{~g})$ was recorded at $T_{0}\left(25 \pm 1^{\circ} \mathrm{C}\right.$ and $75 \% \mathrm{RH})$ while the lowest $(1.519 \mathrm{~g})$ at $T_{7}\left(35 \pm 1^{\circ} \mathrm{C}\right.$ and $55 \%$ $\mathrm{RH})$. Similarly, at $25 \pm 1{ }^{\circ} \mathrm{C}$ in combination with all three humidity levels (55, 65 and 75\%), the highest average cocoon weight was observed $(1.575 \mathrm{~g})$ and average cocoon weight $(1.558 \mathrm{~g})$ observed at $30 \pm 1^{\circ} \mathrm{C}$ while cocoon weight at $35 \pm$ $1^{\circ} \mathrm{C}$ under different conditions of relative humidity showed lowest average cocoon weight $(1.538 \mathrm{~g})$. The comparison of mean values of cocoon weight obtained from eleven inbred silkworm lines presented in Figure 1 revealed that higher cocoon weight was recorded in Pak-2 (1.643), Pak-3 (1.635), Pak-4 (1.632), Pak-1 (1.628), and M-107 (1.626) when larvae were reared at $25 \pm 1^{\circ} \mathrm{C}$ and $70-80 \% \mathrm{RH}$.

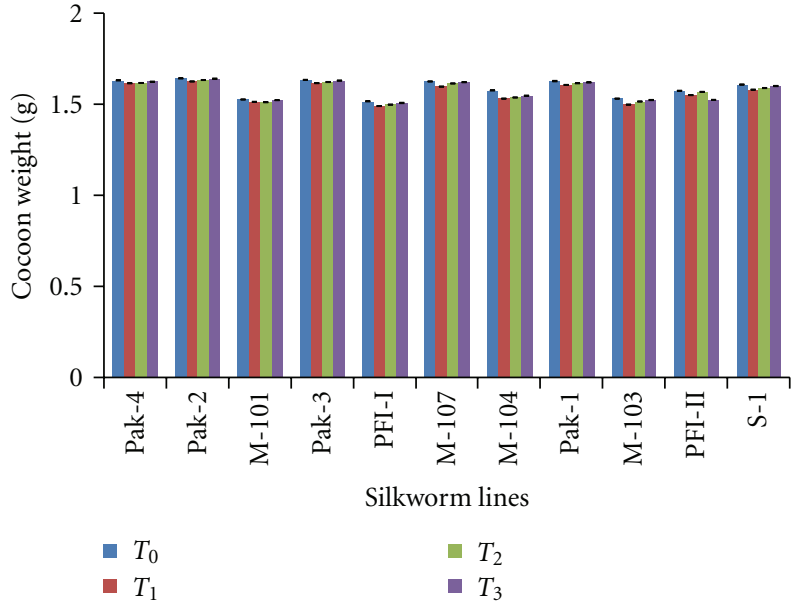

FIGURE 1: Comparative performance of cocoon weight (mean \pm SE) of eleven silkworm lines at $25 \pm 1^{\circ} \mathrm{C}$ in combination with 55,65 , and $75 \% \mathrm{RH}$ and controlled conditions of temperature and $\mathrm{RH}$ (25 $\pm 1^{\circ} \mathrm{C}$ and $70-80 \%$, resp.).

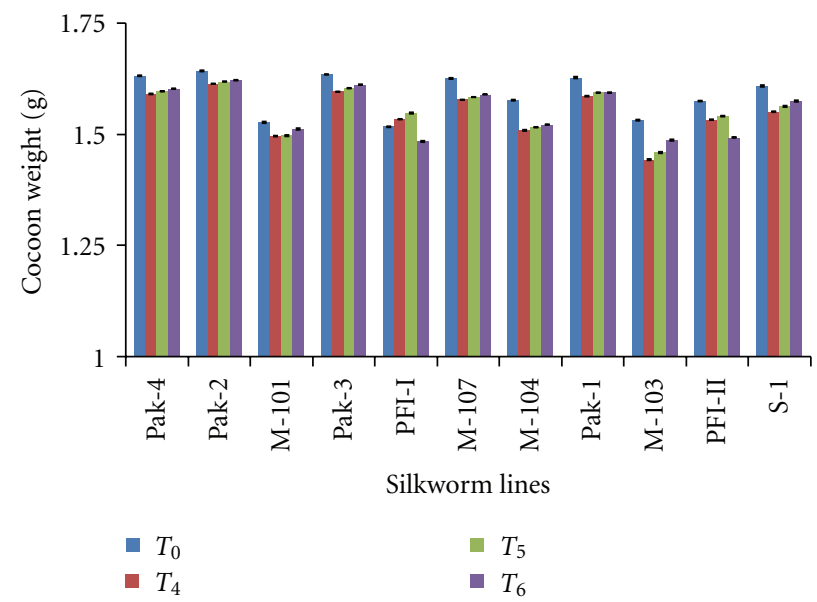

Figure 2: Comparative performance of cocoon weight (mean $\pm \mathrm{SE}$ ) eleven silkworm lines at $30 \pm 1^{\circ} \mathrm{C}$ in combination with 55,65 , and $75 \% \mathrm{RH}$ and controlled conditions of temperature and $\mathrm{RH}(25 \pm$ $1{ }^{\circ} \mathrm{C}$ and $70-80 \%$, resp.).

It was noticed that most of the silkworm lines performed relatively better at $25 \pm 1^{\circ} \mathrm{C}$ at all three combinations of RH $(55,65$ and 75\%). However, it was evident from the data presented in Figure 1 that changes in $\mathrm{RH}$ at a given temperature $\left(25 \pm 1^{\circ} \mathrm{C}\right)$ for even a shorter period of time resulted in lower cocoon weight.

The data shown in Figure 2 clearly indicated that exposure of silkworm larvae to changes in temperature $\left(30 \pm 1^{\circ} \mathrm{C}\right)$ for three hrs resulted in lower cocoon weight as compared to controlled conditions of temperature and humidity (25 $\pm 1^{\circ} \mathrm{C}$ and $\left.70-80 \% \mathrm{RH}\right)$. The data also presented that Pak-3, Pak-2, Pak-4, and M-107 showed relatively higher cocoon weight at all three RH levels (55, 65 and 75\%). The comparative performance of silkworm lines at $35 \pm 1{ }^{\circ} \mathrm{C}$ in combination with three RH levels (55, 65 and 75\%) for three hrs in addition to rearing of silkworm larvae at standard 


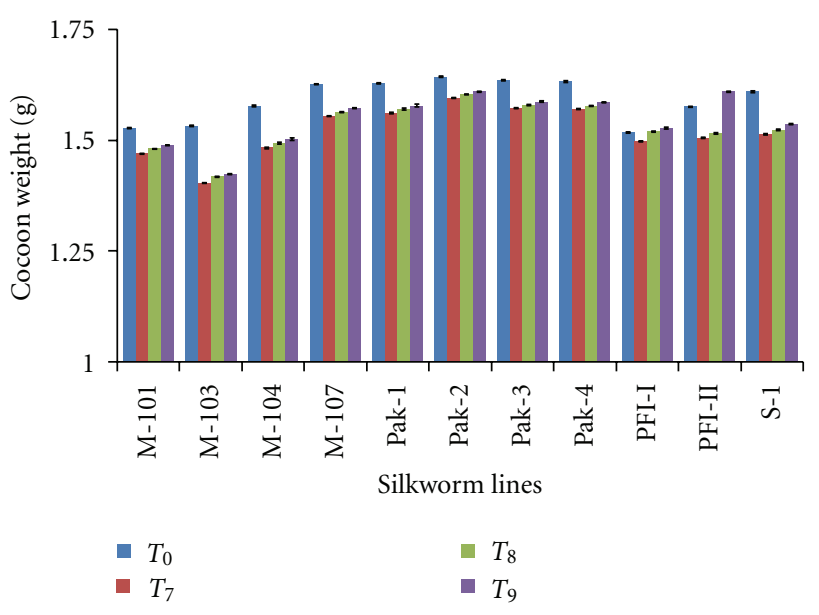

FIGURE 3: Comparative performance of cocoon weight (mean \pm SE) eleven silkworm lines at $35 \pm 1^{\circ} \mathrm{C}$ in combination with 55,65 , and $75 \% \mathrm{RH}$ and controlled conditions of temperature and $\mathrm{RH}(25 \pm$ $1{ }^{\circ} \mathrm{C}$ and $70-80 \%$, resp.).

conditions of temperature and humidity has been presented in Figure 3 that showed lower cocoon weight by almost all silkworm lines. However, Pak-4, Pak-2 and M-107 showed comparatively better performance at all three $\mathrm{RH}$ levels at 35 $\pm 1^{\circ} \mathrm{C}$. It was also observed that the increase in temperature from control $\left(25 \pm 1^{\circ} \mathrm{C}\right)$ during 4 th and 5th larval instar influence the spinning of the larvae which resulted in lower cocoon weight. The data showed that greater variations in cocoon weight of various silkworm lines have been recorded at $30 \pm 11^{\circ} \mathrm{C}$ in all three $\mathrm{RH}$ levels (55, 65 and 75\%). It was also evident from data that higher cocoon weight was observed when the RH was $75 \%$ in addition to controlled conditions rearing as compared to 55 and 65\% RH. Silkworm lines Pak-3, Pak-2, M-101, PFI-I, and M-107 showed the best performance for cocoon yield. The analysis of data also showed that effect of seasons during larval rearing on cocoon weight was significant $\left(F_{1}, 440=10.743, P<0.05\right)$. However, interaction between treatments $\times$ season $\left(F_{9}, 440=0.328, P\right.$ $>0.05)$, line $\times$ season $\left(F_{10}, 440=0.630, P>0.05\right)$, and line $\times$ treatments $\times$ season $\left(F_{90}, 440=0.275, P>0.05\right)$ were not statistically significant.

The performance of inbred silkworm lines clearly indicated the role of their origin and genetic diversity on cocoon output for seed purposes. Higher cocoon weight of Pak-3, Pak-4, and PFI-I prove commercial superiority of these lines. The study infers the need of conservations of these lines and their utilization in hybrid seed production. The reproductive performance of silkworm varies with impertinent climatic factors in addition to physiological status of the parent. The commercial viability of silkworm is dependent on correlation between cocoons, moths, and reproductive potential of the strains. The cocoon weight and reproductive characters were greatly influenced by different temperature regimes. Singh et al. [17] concluded that temperature and humidity are key environmental factors which influence the physiology of insects. Cocoon weight varied due to different treatments of temperature and humidity. Kumar et al. [18] noticed the deleterious effect of adverse temperature and humidity

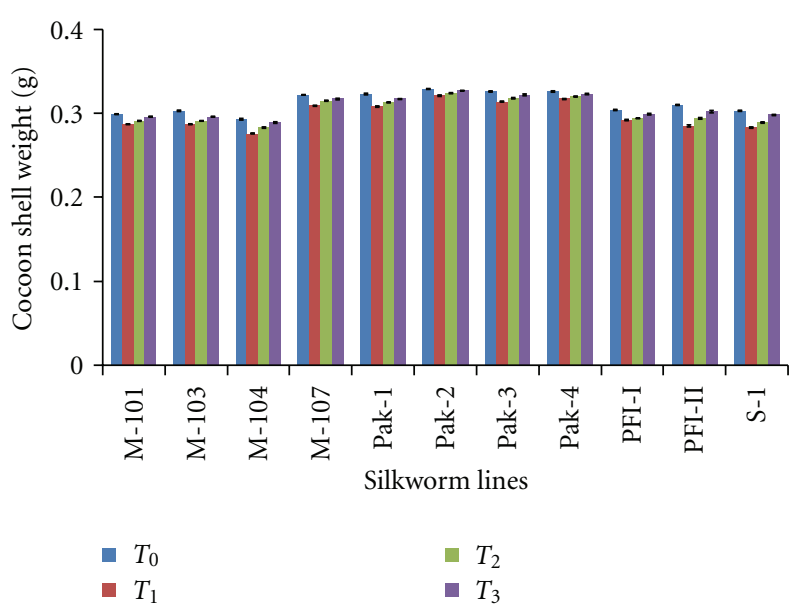

FIGURE 4: Comparative performance of cocoon shell weight of (mean \pm SE) eleven silkworm lines at $25 \pm 1^{\circ} \mathrm{C}$ in combination with 5,65 , and $75 \% \mathrm{RH}$ and controlled conditions of temperature and $\mathrm{RH}\left(25 \pm 1^{\circ} \mathrm{C}\right.$ and $70-80 \%$, resp. $)$.

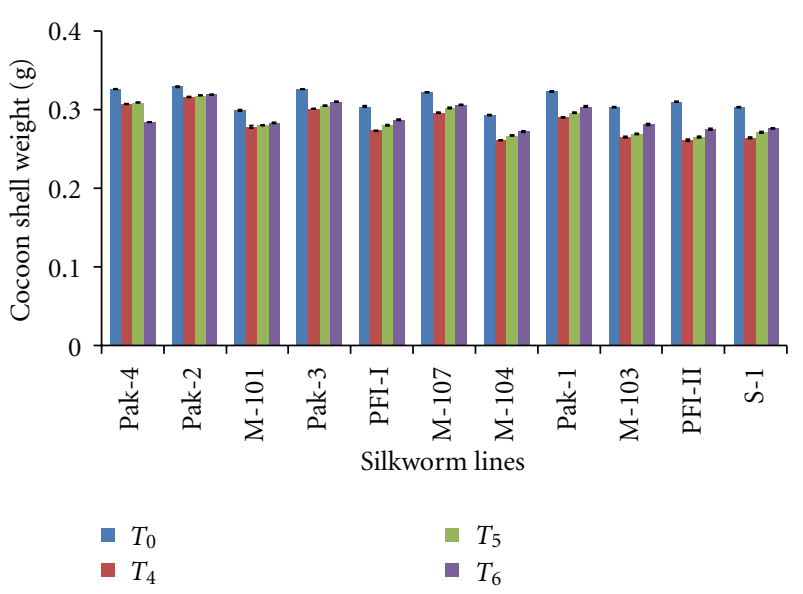

FIGURE 5: Comparative performance of cocoon shell weight (mean $\pm \mathrm{SE}$ ) eleven silkworm lines at $30 \pm 1^{\circ} \mathrm{C}$ in combination with 55, 65 , and $75 \% \mathrm{RH}$ and controlled conditions of temperature and $\mathrm{RH}$ (25 $\pm 1^{\circ} \mathrm{C}$ and $70-80 \%$, resp.).

on various aspects of cocoon including cocoon shape, size, and weight. The variations in relative humidity during late larval stages and spinning affects cocoon weight, cocoon shell weight, filament length, and raw silk percentage adversely qualitatively as well as quantitatively [19]. Wu [20] pointed out that RH and air flow during larval mounting and spinning has greater influence on cocoon formation than other ecological factors maintained during mounting.

3.2. Cocoon Shell Weight (g). The analysis of data indicated that cocoon shell weight of silkworm lines was significantly different $\left(F_{10}, 440=316.98, P<0.05\right)$ and it was also found that treatments affected larvae significantly $\left(F_{9}, 440\right.$ $=277.44, P<0.05)$ during rearing, contributing in variations in cocoon shell weight. The analysis of data showed that interaction of silkworm lines between treatments of 


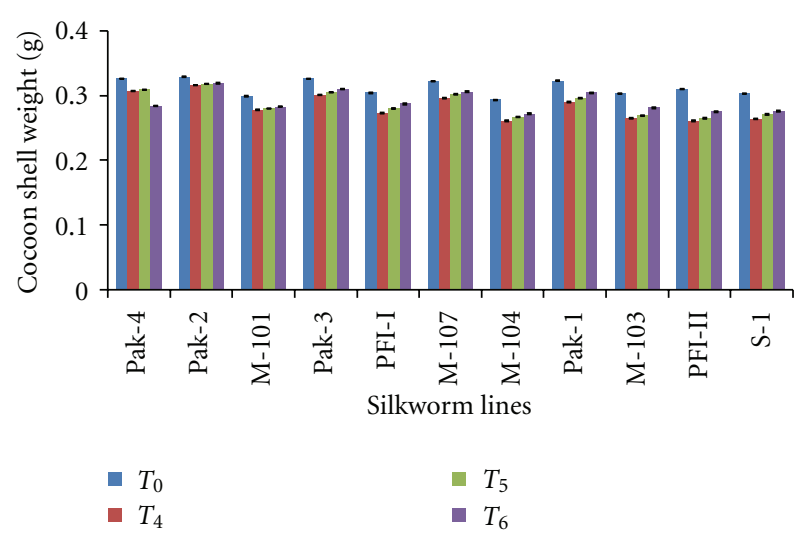

FIGURE 6: Comparative performance of cocoon shell weight (mean $\pm \mathrm{SE}$ ) of eleven silkworm lines at $25 \pm 1^{\circ} \mathrm{C}$ in combination with 55 , 65 , and $75 \% \mathrm{RH}$ and controlled conditions of temperature and $\mathrm{RH}$ $\left(25 \pm 1^{\circ} \mathrm{C}\right.$ and $70-80 \%$, resp.).

temperature and $\mathrm{RH}$ were significantly different $\left(F_{9}, 440=\right.$ $3.696, P<0.05)$. The results showed that cocoon shell weight was variable under different set environmental conditions experienced by larvae during 4 th and 5 th instar. Maximum cocoon shell weight $(0.312 \mathrm{~g})$ was recorded in $T_{0}\left(25 \pm 1^{\circ} \mathrm{C}\right.$ and $75 \% \mathrm{RH})$ while minimum cocoon shell weight $(0.266 \mathrm{~g})$ was presented by $T_{7}\left(35 \pm 1{ }^{\circ} \mathrm{C}\right.$ and $\left.55 \% \mathrm{RH}\right)$. At $25 \pm$ $1{ }^{\circ} \mathrm{C}$ with all three humidity levels $(55,65$ and $75 \%)$, the highest average cocoon shell weight $(0.302 \mathrm{~g})$, at $30 \pm 1^{\circ} \mathrm{C}$ shell weight recovered was $0.286 \mathrm{~g}$ while at $35 \pm 1^{\circ} \mathrm{C}$ lowest average cocoon shell weight $(0.271 \mathrm{~g})$ was recorded.

The mean values of cocoon shell weight obtained from cocoons of eleven inbred silkworm lines presented in Figures 4-6 which showed that better cocoon shell weight was recorded in $T_{0}\left(25 \pm 1^{\circ} \mathrm{C}\right.$ and $\left.70-80 \% \mathrm{RH}\right)$ by Pak-2 (0.329), Pak-3 (0.326), Pak-4 (0.326), Pak-1 (0.323), and M-107 (0.322). It was observed that the silkworm lines performed comparatively better when exposed to $25 \pm 1^{\circ} \mathrm{C}$ at all three $\mathrm{RH}$ levels $(55,65$ and $75 \%)$ instead of $30 \pm 1^{\circ} \mathrm{C}$ and $35 \pm 1^{\circ} \mathrm{C}$ for three hrs during 4 th and 5 th instar. However, it was clear from the results presented in Figure 4 that the variations in $\mathrm{RH}$ at $25 \pm 1^{\circ} \mathrm{C}$ for even a brief period of time results in lower cocoon shell weight. The data given in Figure 5 depicted that exposure of silkworm larvae to relatively higher temperature $\left(30 \pm 1^{\circ} \mathrm{C}\right)$ for three hrs resulted in poor cocoon shell weight as compared to control $\left(25 \pm 1^{\circ} \mathrm{C}\right)$. The data also indicated that Pak-3, Pak-2, Pak-4, and M-107 showed relatively higher cocoon shell weight at $75 \% \mathrm{RH}$ levels as compared to 55 and $65 \% \mathrm{RH}$. The comparative performance of silkworm lines at $35 \pm 1{ }^{\circ} \mathrm{C}$ in combination with 55,65 , and $75 \% \mathrm{RH}$ for three hrs in addition to rearing of silkworm larvae at standard conditions of temperature and humidity $\left(25 \pm 1^{\circ} \mathrm{C}\right.$ and $70-80 \%$ RH, resp.) has been presented in Figure 6 which showed that lower cocoon shell weight was noticed in almost all silkworm lines.

However, Pak-4, Pak-2, and M-107 showed comparatively better performance at various levels of $\mathrm{RH}$ at $35 \pm$ $1{ }^{\circ} \mathrm{C}$. It was also observed that with the shift in temperature from control $\left(25 \pm 1^{\circ} \mathrm{C}\right)$ to higher $\left(35 \pm 1^{\circ} \mathrm{C}\right)$ during 4 th and 5th larval instar influenced the spinning of the larvae yielding lower cocoon shell weight. The highest cocoon shell weight $(\mathrm{g})$ was found in control $\left(25 \pm 1^{\circ} \mathrm{C}\right.$ and $70-80 \%$ $\mathrm{RH})$. The results also indicated that rearing of larvae at 25 $\pm 1^{\circ} \mathrm{C}$ with various humidity levels $(75,65$, and $55 \% \mathrm{RH})$ resulted in higher cocoon shell weight was recovered at $75 \%$ $\mathrm{RH}$; however, it was not significantly different in most of the eleven silkworm lines. It was observed that the performance of silkworm lines for cocoon shell weight was variable under different rearing conditions.

The analysis of data on cocoon shell weight showed that influence of season was not significantly different $\left(F_{1}, 440=\right.$ $0.292, P>0.05)$, interaction between treatments $\times$ season $\left(F_{9}, 440=1.541, P>0.05\right)$, line $\times$ season $\left(F_{10}, 440=0.793, P\right.$ $>0.05)$ and line $\times$ treatments $\times$ season $\left(F_{90}, 440=0.947, P>\right.$ $0.05)$ were statistically not significant. The results exhibited that silkworm cocoon shell weight obtained from cocoon produced by various silkworm lines have been influenced by variations in temperature and relative humidity during larval rearing. These results were in confirmation with those of Falconer [21] who elaborated that recorded better results by making selection from the area of exploitation and expressed that selection pressure on certain character correlated with other quantitative traits of economic importance [22]. Zhao et al. [23] reported that transformation of larvae into pupae and adult depends heavily on shell weight which is greatly influenced by environmental conditions during different stages of silkworm larvae.

3.3. Cocoon Shell Ratio (\%). The data obtained on cocoon shell ratio subjected to statistical analysis which indicated that cocoon shell ratio shown by silkworm lines was significantly different $\left(F_{10}, 440=2231.87, P<0.05\right)$ and it was also found that treatments affected the performance of silkworm larvae significantly $\left(F_{9}, 440=2583.66, P<\right.$ 0.05 ) during rearing which contributed in variations in cocoon shell ratio. The analysis of data on cocoon shell ratio showed that interaction between silkworm lines and treatments (temperature and $\mathrm{RH})$ was significant $\left(F_{9}, 440\right.$ $=51.084, P<0.05)$. The overall pattern of cocoon shell ratio was significantly variable between the treatments with maximum $(19.65 \%)$ in $T_{0}\left(25 \pm 1^{\circ} \mathrm{C}\right.$ and $\left.75 \% \mathrm{RH}\right)$ while lowest $(17.52 \%)$ was observed in $T_{7}\left(35 \pm 1^{\circ} \mathrm{C}\right.$ and $55 \%$ $\mathrm{RH})$. The average cocoon shell ratio $(19.23)$ at $25 \pm 1^{\circ} \mathrm{C}$ followed by 18.52 percent at $30 \pm 1^{\circ} \mathrm{C}$ and 17.78 percent at $35 \pm 1^{\circ} \mathrm{C}$ in combination with 55,65 , and $75 \% \mathrm{RH}$. The data regarding cocoon shell ratio during spring 2007 and autumn 2008 envisaged that cocoon shell ratio was affected significantly by various treatments of temperature and $\mathrm{RH}$. Maximum cocoon shell ratio was obtained from silkworm larvae reared at controlled conditions of temperature and humidity $\left(T_{0}: 25 \pm 1^{\circ} \mathrm{C}\right.$ and $\left.70-80 \% \mathrm{RH}\right)$ as compared to all other combinations of temperature and $\mathrm{RH}$. Maximum cocoon shell ratio (\%) was recorded in Pak-2 (20.03) followed by Pak-4 (19.99), PFI-1 (19.97), and Pak-3 (19.92) which was statistically insignificant with each other but significantly different from M-104 (18.84) and S-1 (18.82). Overall performance of silkworm lines M-101, M-103, M107, Pak-2, and Pak-4 was significantly better than all other 


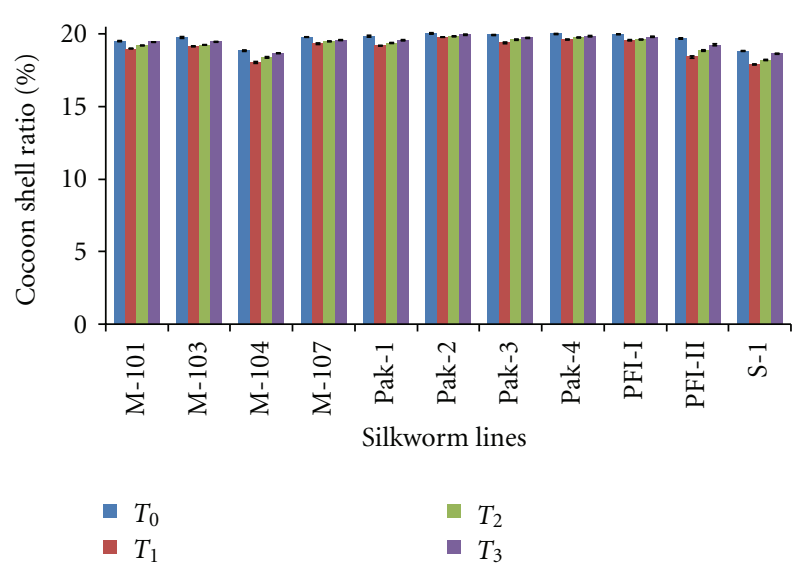

Figure 7: Comparative performance of cocoon shell ratio (mean \pm SE) of eleven silkworm lines at $25 \pm 1^{\circ} \mathrm{C}$ in combination with 55 , 65 , and $75 \% \mathrm{RH}$ and controlled conditions of temperature and $\mathrm{RH}$ (25 $\pm 1^{\circ} \mathrm{C}$ and $70-80 \%$, resp.).

silkworm lines at $25 \pm 1{ }^{\circ} \mathrm{C}$ in combination with 55,65 , and $75 \% \mathrm{RH}$ (Figure 7). The highest cocoon shell ratio at $30 \pm 1{ }^{\circ} \mathrm{C}$ was noticed in Pak-2 (19.58) followed by Pak4 (19.31) which were statistically significant with all other silkworm lines but insignificant with each other at 55\% RH. However, comparatively better performance of silkworm lines was noticed at $75 \% \mathrm{RH}$ as compared to other two levels at $30 \pm 1^{\circ} \mathrm{C}$.

It was also observed that the performance of silkworm lines for cocoon shell ratios of M-107, Pak-1, Pak-2, Pak3 , Pak-4, and PFI-I was not significantly different at $75 \%$ RH (Figure 8). The comparative performance of silkworm lines at $35 \pm 1{ }^{\circ} \mathrm{C}$ showed that higher cocoon shell ratio was harvested at $75 \%$ RH followed by $65 \%$ RH and lowest at $55 \%$ RH in almost all the silkworm lines utilized in the study. The mean values of cocoon shell ratio clearly depicted the rearing of silkworm lines at $35 \pm 1{ }^{\circ} \mathrm{C}$ during 4 th and 5th instar larvae at different $\mathrm{RH}$ levels in comparison with standard conditions of temperature and humidity (Figure 9). The lower mean values of cocoon shell ratio (\%) were obtained when larvae were exposed to $55 \% \mathrm{RH}$ in almost all the silkworm lines. However, significantly better performance of Pak-4 (19.07) and Pak-2 (18.85) from all other was noticed at $55 \% \mathrm{RH}$.

The weight of five cocoons was measured and after removing the pupae shell weight was obtained and then the average cocoon shell ratio was calculated for each silkworm line. Rearing of silkworm larvae at controlled conditions of temperature and humidity substantially influenced the cocoon shell ratio. However, the significant differences in cocoon shell ratio between the larvae reared at control (25 $\pm 1^{\circ} \mathrm{C}$ and $\left.70-80 \% \mathrm{RH}\right)$ and $25 \pm 1,30 \pm 1$, and $35 \pm$ $1{ }^{\circ} \mathrm{C}$ and with all three humidity levels $(55,65$, and $75 \%$ RH) were noticed $(P>0.05)$. The silkworm larvae during 4 th and 5th instar need relatively lower temperature and fluctuations in temperature up to certain limits favor growth and development process of silkworm.

The analysis of data on cocoon shell ratio also showed that effect of seasons during larval rearing on cocoon weight

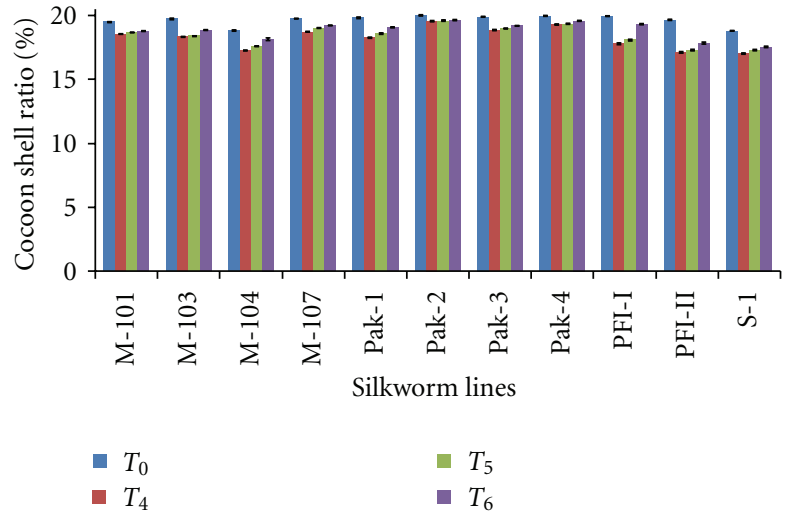

FIGURE 8: Comparative performance of cocoon shell ratio (mean \pm SE) of eleven silkworm lines at $30 \pm 1{ }^{\circ} \mathrm{C}$ in combination with 55 , 65 , and $75 \% \mathrm{RH}$ and controlled conditions of temperature and $\mathrm{RH}$ (25 $\pm 1^{\circ} \mathrm{C}$ and $70-80 \%$, resp.).

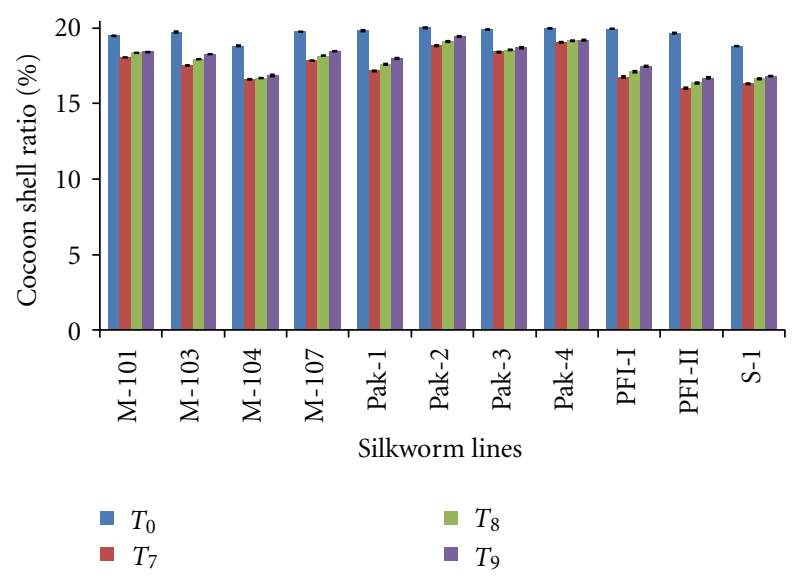

FIGURE 9: Comparative performance of cocoon shell ratio (mean \pm SE) of eleven silkworm lines at $25 \pm 1{ }^{\circ} \mathrm{C}$ in combination with 55 , 65 , and $75 \% \mathrm{RH}$ and controlled conditions of temperature and $\mathrm{RH}$ (25 $\pm 1^{\circ} \mathrm{C}$ and $70-80 \%$, resp.).

was significant $\left(F_{1}, 440=8.745, P<0.05\right)$. However, interaction between treatments $\times$ season $\left(F_{9}, 440=3.259\right.$, $P<0.05)$, line $\times$ season $\left(F_{10}, 440=0.829, P<0.05\right)$ was significant but line $\times$ treatments $\times$ season $\left(F_{90}, 440=0.444\right.$, $P>0.05)$ was not statistically significant. The recommended humidity levels during various instars ranges from $85-70 \%$ with lowest in the final instar [17]. Kumar et al. [24] concluded that higher levels of humidity and temperature during various stages of life cycle of silkworm resulted in poor performance of pure races, foundation crosses, and hybrids for cocoon size and shape. The cocoon formation process is greatly influenced by fluctuating conditions of environment, particularly temperature and humidity [25]. The influences of ambient temperature and relative humidity were investigated during larval rearing on cocoon shell ratio. It was noticed that average cocoon shell ratio of a single cocoon was significantly less in almost all silkworm lines as compared to other treatments of temperature and RH. Gowda and Reddy [19] concluded that the adverse effect 


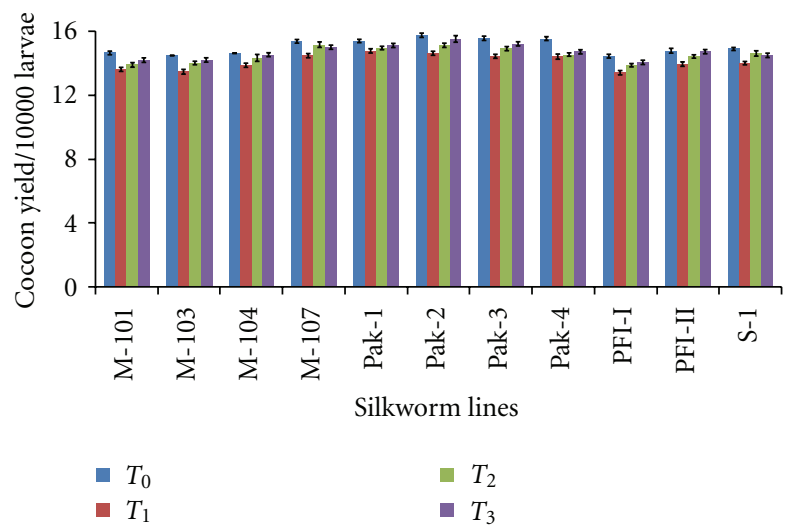

FIGURE 10: Comparative performance of cocoon yield (mean \pm SE) of eleven silkworm lines at $25 \pm 1^{\circ} \mathrm{C}$ in combination with 55,65 , and $75 \% \mathrm{RH}$ and controlled conditions of temperature and $\mathrm{RH}$ ( 25 $\pm 1^{\circ} \mathrm{C}$ and $70-80 \% \mathrm{RH}$, resp.).

of high temperature and high $\mathrm{RH}$ was relatively higher on rearing and spinning of silkworm larvae than lower temperature.

3.4. Filament Length $(\mathrm{m})$. The data obtained on cocoon shell ratio subjected to statistical analysis which indicated that filament length shown by silkworm lines was significantly different $\left(F_{10}, 440=461.06, P<0.05\right)$. It was also observed that effect of treatments (temperature and $\mathrm{RH}$ ) was significant $\left(F_{9}, 440=800.150, P<0.05\right)$ in determining the filament length. The analysis of data on filament length indicated that interaction between silkworm lines and treatments of temperature and $\mathrm{RH}$ was not significantly different $\left(F_{90}\right.$, $440=4.622, P>0.05)$. Average filament length differences under different temperature and RH (Figures 10, 11, and 12) indicated that higher filament length was recovered at $25 \pm 1{ }^{\circ} \mathrm{C}$ with $70-80 \% \mathrm{RH}$ followed by $25 \pm 1^{\circ} \mathrm{C}$ with $75 \% \mathrm{RH}, 25 \pm 1^{\circ} \mathrm{C}$ with $65 \% \mathrm{RH}$ and $25 \pm 1{ }^{\circ} \mathrm{C}$ with $55 \% \mathrm{RH}$ as compared to exposures of 4 th and 5 th instar larvae to variable temperature and humidity regimes $(30$ $\pm 1^{\circ} \mathrm{C} \& 35 \pm 1^{\circ} \mathrm{C}$; in combination with 55,65 and $75 \%$ $\mathrm{RH})$. Maximum filament length (m) was shown by Pak4 (716) followed by Pak-2 (713) and M-101(709) which were significantly different from filament length recovered from all other silkworm lines. It was obvious from data that exposures to higher temperature (above $25 \pm 1{ }^{\circ} \mathrm{C}$ ) and relative humidity for a certain period of time ( $03 \mathrm{hrs})$ resulted in lowering filament length recovery. The data clearly depicted that rearing of silkworm larvae at standard controlled conditions of temperature and humidity $(25 \pm$ $1{ }^{\circ} \mathrm{C}$ and $\left.70-80 \% \mathrm{RH}\right)$ throughout the larval period resulted in higher filament length as compared to rearing of 4th and 5 th instar larvae at variable temperature and $\mathrm{RH}$ conditions $\left(25 \pm 1^{\circ} \mathrm{C}, 30 \pm 1^{\circ} \mathrm{C} \& 35 \pm 1{ }^{\circ} \mathrm{C}\right.$ in combination with 55,65 and $75 \%$, resp.).

Longest filament length $(682.43 \mathrm{~m})$ was recorded in $T_{0}$ $\left(25 \pm 1^{\circ} \mathrm{C}\right.$ and $\left.75 \pm 5 \% \mathrm{RH}\right)$ and shortest $(593.3 \mathrm{~m})$ was observed in $T_{7}\left(35 \pm 1{ }^{\circ} \mathrm{C}\right.$ and $\left.50 \pm 5 \% \mathrm{RH}\right)$. The performance of silkworm lines when exposed to $25 \pm 1^{\circ} \mathrm{C}$

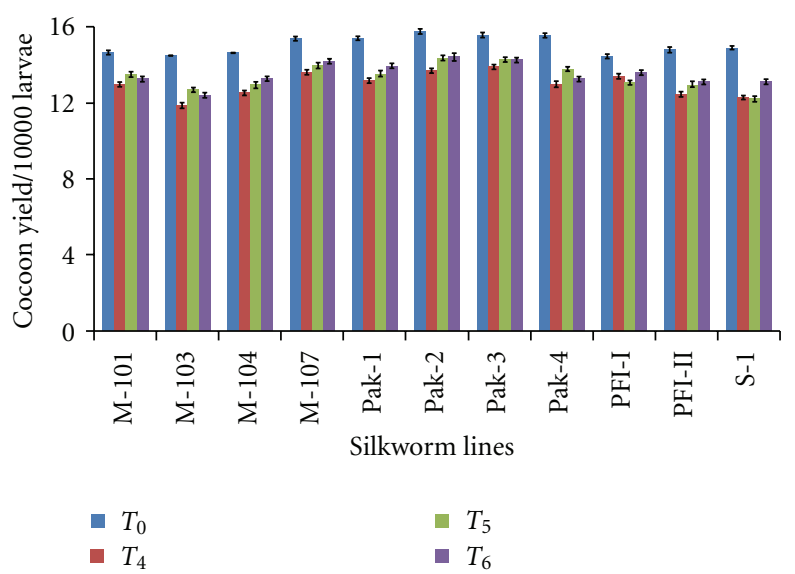

FIGURE 11: Comparative performance of cocoon yield (mean \pm SE) of eleven silkworm lines at $30 \pm 1^{\circ} \mathrm{C}$ in combination with 55, 65, and $75 \% \mathrm{RH}$ and controlled conditions of temperature and $\mathrm{RH}$ (25 $\pm 1^{\circ} \mathrm{C}$ and $70-80 \% \mathrm{RH}$, resp.).

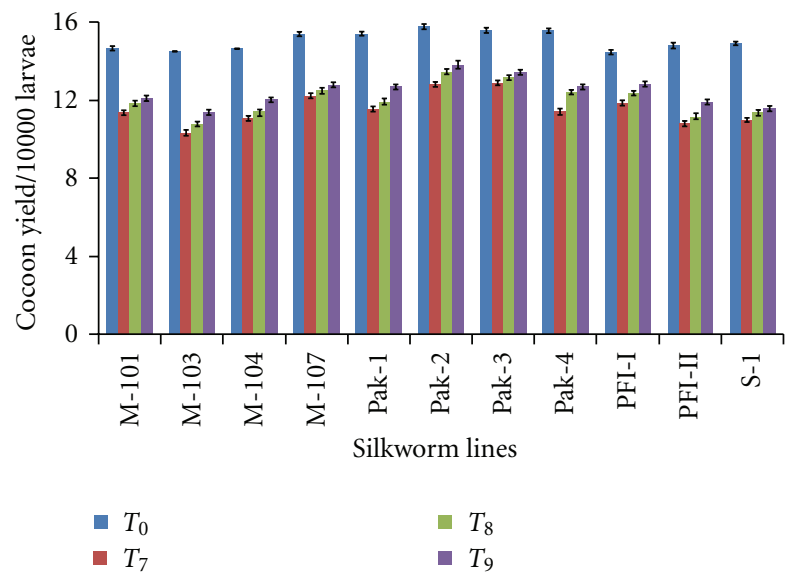

FIGURE 12: Comparative performance of cocoon yield (mean \pm SE) of eleven silkworm lines at $35 \pm 1{ }^{\circ} \mathrm{C}$ in combination with 55,65 , and $75 \% \mathrm{RH}$ and controlled conditions of temperature and $\mathrm{RH}$ ( 25 $\pm 1^{\circ} \mathrm{C}$ and $70-80 \%$, resp.).

showed that the average filament obtained was $646.69 \mathrm{~m}$ while at $30 \pm 1{ }^{\circ} \mathrm{C}$ the mean filament length recorded was $634 \mathrm{~m}$ and $600.38 \mathrm{~m}$ at $35 \pm 1{ }^{\circ} \mathrm{C}$ with various combinations of relative humidity. Silkworm lines Pak-4, M-101, Pak3 , Pak-2 and PFI-I showed the better performance when comparing filament length attained by exposing 4th and 5 th instar larvae to various combinations of temperature and humidity (Figures 10-12). However, higher values of filament length were achieved in control $\left(T_{0}: 25 \pm 1^{\circ} \mathrm{C}\right.$ and $75 \pm 5 \% \mathrm{RH})$ by Pak- 4 , Pak-2, and M-101 contrary to the other silkworm lines used in the study, especially S-1, PFI-II, M-104, and Pak-1.

The mean values of filament length obtained from eleven inbred silkworm lines under different conditions during 4th and 5th instar larval rearing correspond to significant differences within a treatment. However, level of variations differed with each silkworm line under certain treatment 


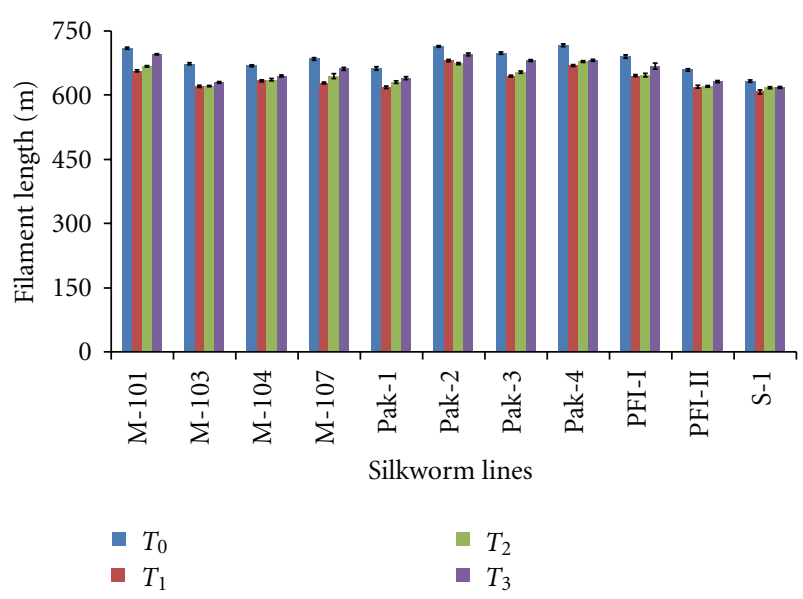

FIGURE 13: Comparative performance of filament length (mean \pm SE) of eleven silkworm lines at $25 \pm 1^{\circ} \mathrm{C}$ in combination with 55 , 65 , and $75 \% \mathrm{RH}$ and controlled conditions of temperature and $\mathrm{RH}$ ( $25 \pm 1^{\circ} \mathrm{C}$ and $70-80 \% \mathrm{RH}$, resp.).

(temperature and humidity) with higher values in Pak-4, M-101, Pak-2, and PFI-I and those relatively lower in S-1, M-104, and PFI-II (Figure 12). The analysis of data showed that influence of season during larval rearing on filament length was not significantly different $\left(F_{1}, 440=1.852, P\right.$ $>0.05)$, interaction between treatments $\times$ season $\left(F_{9}, 440\right.$ $=1.173, P>0.05)$, line $\times$ season $\left(F_{10}, 440=0.156, P>\right.$ $0.05)$, and line $\times$ treatments $\times$ season $\left(\mathrm{F}_{90}, 440=0.484, P>\right.$ $0.05)$ were statistically not significant. These findings showed confirmation of earlier works carried out by Benchamin et al. [26] and Tazima [27] who observed similar results in their studies on the effect of temperature and humidity on the growth and development of silkworm races. Several reports $[9,28,29]$ demonstrated that silkworms were more sensitive to high temperature during 4th and 5th stages and hence were recommended for the recognition and selection of thermotolerant silkworm breeds, under high temperature conditions.

3.5. Cocoon Yield ( $\mathrm{kg}$ per 10,000 Larvae). The data on cocoon yield ( $\mathrm{kg} / 10,000$ larvae) obtained from eleven inbred silkworm lines has been presented in Figures 13-15 which pointed out that cocoon yield was significantly higher when the larvae reared at standard conditions of temperature and $\mathrm{RH}$ throughout larval period. The significant differences among the treatments $\left(F_{9}, 440=497.28, P<0.05\right)$, silkworm lines $\left(F_{10}, 440=102.113, P<0.05\right)$, and interaction between treatments and silkworm lines $\left(F_{90}, 440=3.145, P<0.05\right)$ were observed for cocoon yield.

Maximum cocoon yield was shown by Pak-2 (14.37), Pak-3 (14.21), Pak-4 (13.58), Pak-1 (13.70), M-107 (13.94), and PFI-1 (13.29). The variation on temperature and humidity affected the cocoon yield of almost all the silkworm lines. Maximum cocoon yield $(15.06 \mathrm{~kg} / 10,000$ larvae) was found at $25 \pm 1{ }^{\circ} \mathrm{C}$ and $75 \% \mathrm{RH}\left(T_{0}\right)$; the highest average cocoon yield $(14.46 \mathrm{~kg} / 10,000$ larvae) was observed at $25 \pm$ $1{ }^{\circ} \mathrm{C}$ with 55,65 , and $75 \% \mathrm{RH}$ followed by $25 \pm 1^{\circ} \mathrm{C}$ with 55,65 , and $75 \% \mathrm{RH}$ which showed average cocoon yield of

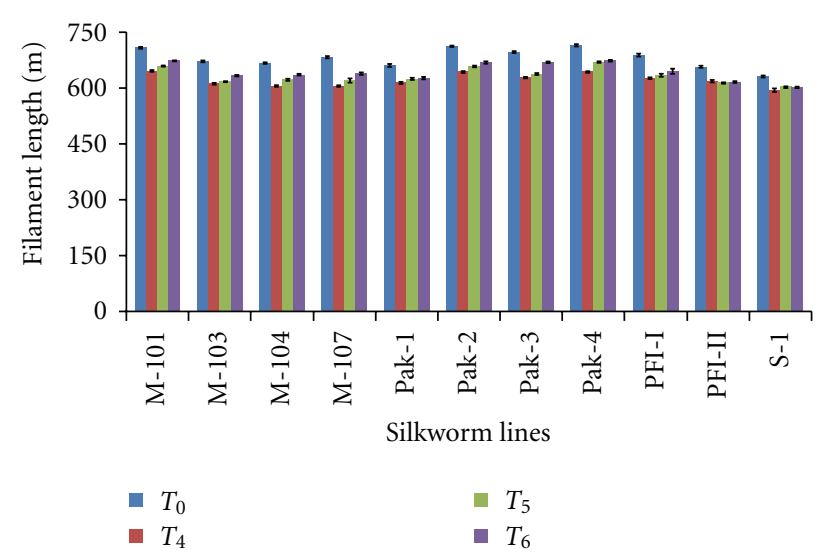

FIGURE 14: Comparative performance of filament length (mean \pm SE) of eleven silkworm lines at $30 \pm 1{ }^{\circ} \mathrm{C}$ in combination with 55 , 65 , and $75 \% \mathrm{RH}$ and controlled conditions of temperature and $\mathrm{RH}$ (25 $\pm 1^{\circ} \mathrm{C}$ and $70-80 \%$, resp.).

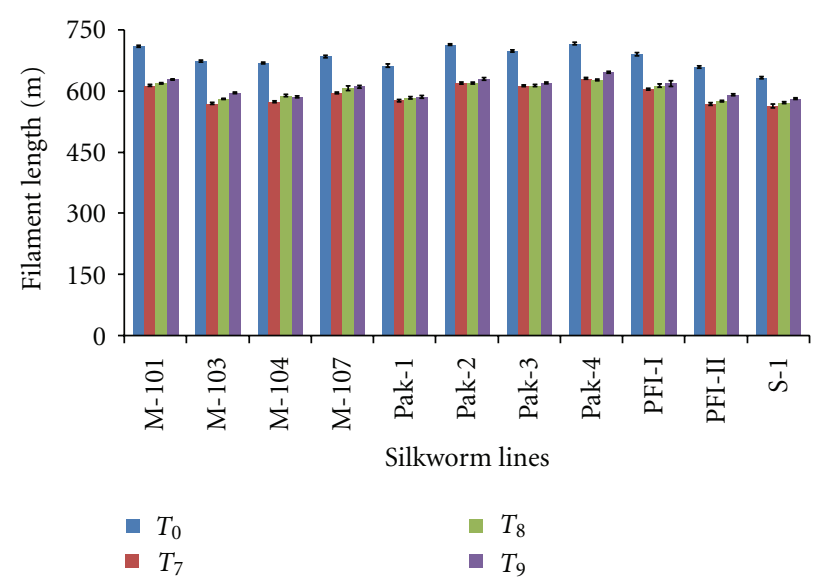

FIGURE 15: Comparative performance of filament length (mean \pm $\mathrm{SE}$ ) of eleven silkworm lines at $35 \pm 1^{\circ} \mathrm{C}$ in combination with 55 , 65 , and $75 \% \mathrm{RH}$ and controlled conditions of temperature and $\mathrm{RH}$ (25 $\pm 1^{\circ} \mathrm{C}$ and $70-80 \%$, resp.).

$13.32 \mathrm{~kg} / 10,000$ larvae and $12.02 \mathrm{~kg} / 10,000$ at $35 \pm 1^{\circ} \mathrm{C}$ with 55,65 , and $75 \% \mathrm{RH}$. The best cocoon yield was observed in the control $\left(T_{0}\right)$ for all the inbred silkworm lines.

The highest average cocoon yield was observed in $T_{0}$ (15.06), followed by $T_{3}$ (14.72), $T_{2}$ (14.55), $T_{1}$ (14.11), and $T_{4}$ (13.54). It was obvious from results (Figures 13-15) that almost all the silkworm lines performed relatively better at 25 $\pm 1^{\circ} \mathrm{C}$ in combination with all three levels of $\mathrm{RH}(55,65$, and $75 \%)$ as compared to $30 \pm 1^{\circ} \mathrm{C}$ and at $35 \pm 1^{\circ} \mathrm{C}$. However, it was found that changes in $\mathrm{RH}$ at a given temperature $(25$ $\pm 1{ }^{\circ} \mathrm{C}, 30 \pm 1{ }^{\circ} \mathrm{C}$, and $35 \pm 1{ }^{\circ} \mathrm{C}$ ) even for a shorter period of time resulted in lower cocoon yield. The data shown in Figure 14 clearly indicated that exposure of silkworm larvae to changes in temperature $\left(30 \pm 1^{\circ} \mathrm{C}\right)$ for three hrs resulted in poor cocoon weight as compared to control. The data also presents that Pak-3, Pak-2, Pak-4, and M-107 showed relatively higher cocoon weight at all three $\mathrm{RH}$ levels $(55,65$ and $75 \%$ ). The comparative performance of silkworm lines 
TABLE 2: Estimation of evaluation index values for cocoon weight, shell weight, shell ratio, yield and filament length of eleven silkworm lines reared at different conditions of temperature and $\mathrm{RH}$.

\begin{tabular}{|c|c|c|c|c|c|c|c|}
\hline \multicolumn{8}{|c|}{ Evaluation index values } \\
\hline Silkworm Lines & $\begin{array}{l}\text { Cocoon weight } \\
(\mathrm{g})\end{array}$ & $\begin{array}{l}\text { Shell weight } \\
\text { (g) }\end{array}$ & $\begin{array}{c}\text { Shell ratio } \\
(\%)\end{array}$ & $\begin{array}{c}\text { Yield } \\
(\mathrm{Kg} / 10,000 \text { larvae })\end{array}$ & $\begin{array}{l}\text { Filament Length } \\
(\mathrm{m})\end{array}$ & $\begin{array}{l}* \text { Cumulative EI } \\
\text { Value }\end{array}$ & $\begin{array}{c}\text { Ranking of } \\
\text { silkworm lines }\end{array}$ \\
\hline M-101 & 59.86 & 65.45 & 47.75 & 62.61 & 63.22 & 59.15 & 2 \\
\hline M-103 & 32.83 & 44.53 & 46.78 & 33.26 & 41.77 & 40.51 & 9 \\
\hline M-104 & 42.81 & 41.49 & 45.71 & 42.44 & 43.81 & 43.33 & 8 \\
\hline Pak-1 & 51.54 & 45.66 & 47.08 & 44.60 & 48.59 & 49.26 & 7 \\
\hline M-107 & 41.37 & 41.01 & 46.76 & 55.39 & 42.20 & 50.03 & 4 \\
\hline Pak-2 & 58.99 & 56.66 & 46.90 & 55.56 & 53.16 & 56.37 & 3 \\
\hline Pak-3 & 56.76 & 54.53 & 46.63 & 42.18 & 56.53 & 52.83 & 5 \\
\hline Pak-4 & 62.74 & 62.59 & 47.65 & 65.34 & 64.84 & 61.42 & 1 \\
\hline PFI-I & 57.73 & 59.85 & 50.35 & 58.39 & 61.66 & 52.62 & 6 \\
\hline PFI-II & 46.12 & 40.35 & 45.76 & 45.13 & 39.88 & 40.37 & 11 \\
\hline S-1 & 39.24 & 37.91 & 45.50 & 45.09 & 34.34 & 40.45 & 10 \\
\hline
\end{tabular}

${ }^{*}$ The silkworm lines were ranked by establishing total cumulative indices.

at $35 \pm 1^{\circ} \mathrm{C}$ in combination with three $\mathrm{RH}$ levels for three hrs in addition to rearing of silkworm larvae at standard conditions of temperature and humidity has been presented (Figure 15) that showed lower cocoon weight noticed in almost all silkworm lines. However, Pak-4, Pak-2, and M107 showed comparatively better performance at all three $\mathrm{RH}$ levels at $35 \pm 1{ }^{\circ} \mathrm{C}$. It was also observed that with the increase in temperature from control $\left(25 \pm 1^{\circ} \mathrm{C}\right)$ during 4 th and 5th larval instar influenced the spinning of the larvae yielding lower cocoon weight. The Performance of silkworm lines at $25^{\circ} \mathrm{C}$ is better than the other two temperatures, that is, $30^{\circ} \mathrm{C}$ and $35^{\circ} \mathrm{C}$. However, it is evident from the data that low humidity level in combination with various temperature levels indicate the cocoon yield.

The relative humidity of $75 \%$ showed non significant differences with the control. However, significant decline in cocoon yield $(\mathrm{kg} / 10,000$ larvae) was observed when the relative humidity was lowered from 75 to $55 \% \mathrm{RH}$. The performance of inbred silkworm lines during autumn and spring season is presented in Figure 9. The variations among different silkworm lines were not significantly different. The analysis of data also showed that effect of seasons during larval rearing on cocoon yield was insignificant $\left(F_{1}, 440=\right.$ $1.403, P>0.05)$. However, interaction between treatments $\times$ season $\left(F_{9}, 440=0.286, P>0.05\right)$, line $\times$ season $\left(F_{10}\right.$, $440=1.340, P>0.05)$ and line $\times$ treatments $\times$ season $\left(F_{90}, 440=0.368, P>0.05\right)$ were not statistically significant. The comparative performance indicated that during spring season cocoon yield was higher than autumn in almost all the silkworm lines. The slight variation in the cocoon yield may be due to notional affected during the two seasons (autumn and spring) in the leaf contest. This indicated that the rearing of the silkworm larvae under standard conditions on humidity results in higher cocoon yield significant. Pak2, Pak-1, Pak-4 and M-107 showed higher cocoon yield with non significant with each other. It was noticed that rearing of temperature on $35^{\circ} \mathrm{C}$ was not suitable for the larvae as the lower cocoon yield all the relative humidity levels at $35^{\circ} \mathrm{C}$. Average cocoon yield was maximum Pak-2 followed by Pak-3 and M-107. It was also observed that cocoon yield that statically in significant M-101, M-104, PFI-II and S1. In commercial crop seasons (autumn and spring) the quantitative traits are stressed due to congenial weather and quality of feed.

The study infers the need of conservations of these lines and their utilization in hybrid seed production. The sericulture is practiced by poor farmers with little resources which results in rearing larvae under prevailing conditions of environment. In commercial crop seasons (autumn and spring) the quantitative traits are stressed due to congenial weather and quality of feed. Legay [30] found that cocoon production is chiefly dependent on larval nutrition and nutritive value of mulberry leaves and conversion efficiency of larvae which is affected by weather conditions. Khawaja [31] reared silkworm larvae during autumn and spring and stated that higher temperature and humidity resulted in poor growth and low quality cocoons.

The evaluation index method has been extensively used by many researchers for the analysis of breeds [16, 32-35] for the selection of suitable parents for utilization in various breeding programmes as for obtaining superior silkworm hybrids. The EI value for the selection of silkworm lines was 50 or $>50$ for positive traits and 50 or $<50$ for negative traits (larval mortality). The silkworm lines which registered in previously mentioned range for positive and negative traits were thought to be of greater economic importance. The results of evaluation index method for various parameters of eleven inbred silkworm lines have been shown in Table 2 . Evaluation Index (EI) was employed for short listing of silkworm lines by considering various economic traits. The performance shown by eleven inbred silkworm lines for ten traits, individual indices were calculated for each of the ten traits (Table 2). The indices calculated from all the traits under consideration in each silkworm line were combined 
to calculate cumulative EI values for each line for each trait. Out of eleven inbred silkworm lines reared during autumn 2007 and spring 2008, six lines scored (Pak-2 (56.37), Pak3 (52.83), Pak-4 (61.42), M-101 (59.15), M-107 (52.62) and PFI-I (50.03)) cumulative EI value greater than 50 while rest of the silkworm lines were unable to obtain standard score of 50. Evaluation index method for breed selection enhances the chances of silkworm strain selection on the basis of overall performance for various traits of economic significance [36].

\section{References}

[1] M. Hussain, S. A. Khan, M. Naeem, and A. U. Mohsin, "Effect of relative humidity on factors of seed cocoon production in some inbred silk worm (Bombyx mori) lines," International Journal of Agriculture and Biology, vol. 13, no. 1, pp. 57-60, 2011.

[2] K. Rajesh and K. Elangovan, "Rearing performance of Eri silkworm, Philosamia ricini in monsoon season of Uttar pradesh," Asian Journal of Experimental Biological Sciences, vol. 1, no. 2, pp. 303-310, 2010.

[3] V. Thiagarajan, S. K. Bhargava, M. Rameshbabu, and B. Nagaraj, "Differences in seasonal performance of twenty-six strains of silkworm, Bombyx mori (Bombycidae)," Journal of the Lepidopterists' Society, vol. 47, pp. 331-337, 1993.

[4] J. Nacheva and Junka, "Phenotypic and genotypic characterization of silkworm character during the different seasons of silkworm feeding," Genetics Selection Evolution, vol. 22, no. 3, pp. 242-247, 1989.

[5] K. Nagalakshmamma and P. Naga Jyothi, "Studies on commercial exploitation of selected multivoltine races of the silkworm bombyx mori L. in different seasons of Rayalaseema region (a. p.) in india," The Bioscan, vol. 5, no. 1, pp. 31-34, 2010.

[6] R. B. Thapa and N. P. Ghimire, "Performance of mulberry silkworm (Bombyx mori L.) under leaf and shoot feeding methods," Journal of the Institute of Agriculture and Animal Science, vol. 26, pp. 83-86, 2005.

[7] J. R. Hazel, "Thermal adaptation in biological membranes: is homeoviscous adaptation the explanation?" Annual Review of Physiology, vol. 57, pp. 19-42, 1995.

[8] C. W. Willmer, G. Stone, and I. Johnston, Environmental Physiology of Animals, Blackwell Science, Oxford, UK, 2004.

[9] Y. Tazima and A. Ohnuma, "Preliminary experiments on the breeding procedure for synthesizing a hightemperature resistant commercial strain of the silkworm, Bombyx mori L.," Reports of the Silk Science Research Institute, vol. 43, pp. 1-16, 1995.

[10] H. Lakshmi and Chandrashekaraiah, "Identification of breeding research material for the development of thermo-tolerant breeds of silkworm, Bombyx mori," Journal of Experimental Zoology India, vol. 10, no. 1, pp. 55-63, 2007.

[11] P. P. Srivastava, P. K. Kar, A. K. Awasthi, and S. Raje Urs, "Identification and association of ISSR markers for thermal stress in polyvoltine silkworm Bombyx mori," Russian Journal of Genetics, vol. 43, no. 8, pp. 858-864, 2007.

[12] S. Krishnaswami, "New technology of silkworm rearing," CSR and TI, Bulletin 2, Central Silk Board, Bangalore, India, 1978.

[13] S. Krishnaswami, "Evolution of new bivoltine race for traditionally multivoltine areas of south India," Indian Silk, vol. 22, no. 1, pp. 3-11, 1983.
[14] C. G. Rao, S. V. Seshagiri, C. Ramesh et al., "Evaluation of genetic potential of the polyvoltine silkworm, Bombyx mori L. germplasm and identification of parents for breeding programme," Journal of Zhejiang University-Science B, vol. 7, no. 3, pp. 215-220, 2006.

[15] R. G. D. Steel and J. H. Torrie, Principles and Procedures of Statistics, McGraw-Hill, New York, NY, USA, 1981.

[16] Y. Mano, N. Kumar, S. Basavaraja, M. H. K. Reddy, and R. K. Datta, "A new method to select promising silkworm breeds /combinations," Indian Silk, vol. 31, 53 pages, 1993.

[17] T. Singh, M. M. Bhat, and M. K. Ashraf, "Insect adaptations to changing environments-temperature and humidity," International Journal of Industrial Entomology, vol. 19, no. 1, pp. 155-164, 2009.

[18] N. S. Kumar, H. K. Basavaraja, B. N. Gowda et al., "Effect of high temperature and high humidity on the post cocoon parameters of parents, foundation crosses, single and double hybrids of bivoltine silkworm, Bombyx mori L.," Indian Journal of Sericulture, vol. 42, no. 2, pp. 162-168, 2003.

[19] B. N. Gowda and N. M. Reddy, "Influence of different environmental conditions on cocoon parameters and their effects on reeling performance of bivoltine hybrids of silkworm, Bombyx mori," International Journal of Industrial Entomology, vol. 14, no. 1, pp. 15-21, 2007.

[20] S. T. Wu, "Management after cocooning process I," Journal of Sericultural Science of Japan, vol. 15, pp. 62-65, 1976.

[21] D. S. Falconer, "Selection in different environments: effects on environmental sensitivity (reaction norm) and on mean performance," Genetical Research, vol. 56, no. 1, pp. 57-70, 1990.

[22] K. Kobari and N. Fujimoto, "Studies on the selection of cocoon filament length and cocoon filament size in Bombyx mori," Nissenzatsu, vol. 35, pp. 427-434, 1966.

[23] H. P. Zhao, X. Q. Feng, S. W. Yu, W. Z. Cui, and F. Z. Zou, "Mechanical properties of silkworm cocoons," Polymer, vol. 46, no. 21, pp. 9192-9201, 2005.

[24] N. S. Kumar, H. K. Basavaraja, N. M. Reddy, and S. B. Dandin, "Effect of high temperature and high humidity on the quantitative traits of parents, foundation crosses, single and double hybrids of bivoltine silkworm, Bombyx mori L.," International Journal of Industrial Entomology, vol. 6, no. 2, pp. 197-202, 2003.

[25] Y. L. Ramachandra, G. Bali, and S. Padmalatha Rai, "Effect of temperature and relative humidity on spinning behaviour of silkworm (Bombyx mori. L)," Indian Journal of Experimental Biology, vol. 39, no. 1, pp. 87-89, 2001.

[26] K. V. Benchamin, M. S. Jolly, and D. A. I. Benjamin, Study on the Reciprocal Crosses of Multivoltine $\times$ Bivoltine with Special Reference to the Use of Bivoltine Hybrid as a Parent, National Seminar on Silk Research and Development, Bangalore, India, 1983.

[27] Y. Tazima, "A view on the improvement of Mysore breeds," in Proceedings of the International Congress Tropical Sericulture, pp. 1-5, February 1988.

[28] S. Ueda and H. Lizuka, "Studies on the effects of rearing temperature affecting the health of silkworm larvae and upon the quality of cocoons I. Effect of temperature in each instar," Acta Sericolo. Japan, vol. 41, pp. 6-21, 1962.

[29] T. Shirota, "Selection of healthy silkworm strain through high temperature rearing of fifth instar larvae," Reports of the Silk Science Research Institute, vol. 40, pp. 33-40, 1992.

[30] J. M. Legay, "Recent advances in silkworm nutrition," Annual Review of Entomology, vol. 3, pp. 75-86, 1958. 
[31] Khawaja, Comparative studies on the prospects of rearing silkworm (Bombyx mori L.) during autumn and spring seasons at Faisalabad, M.S. thesis, Department of Entomology University of Agriculture Faisalabad, Pakistan, 1989.

[32] J. C. Gower, "A general coefficient of similarity and some of its properties," Biometrics, vol. 27, no. 4, pp. 857-871, 1971.

[33] K. Ramesh-Babu, S. Ramakrishna, Y. Harish-Kumar-Reddy et al., "Metabolic alterations and molecular mechanism in silkworm larvae during viral infection: a review," African Journal of Biotechnology, vol. 8, no. 6, pp. 899-907, 2009.

[34] C. G. P. Rao, C. Ramesh, m. Chandrashekaraiah et al., "Evaluation of polyvoltine hybrids based on silk productivity in silkworm, Bombyx mori L."' International Journal of Industrial Entomology, vol. 8, no. 2, pp. 181-187, 2004.

[35] M. Hussain, S. A. Khan, and M. Aslam, "Evaluation of genetic potential of inbred pure lines of silkworm for breeding and cocoon production in Pakistan," African Journal of Food Science, vol. 4, no. 5, pp. 300-302, 2010.

[36] S. K. Bhargava, v. Thiagarajan, and M. K. Majumbdar, "Impact of silkworm breeds on reeling parameters," The Indian Textile Journal, vol. 104, pp. 66-69, 1993. 

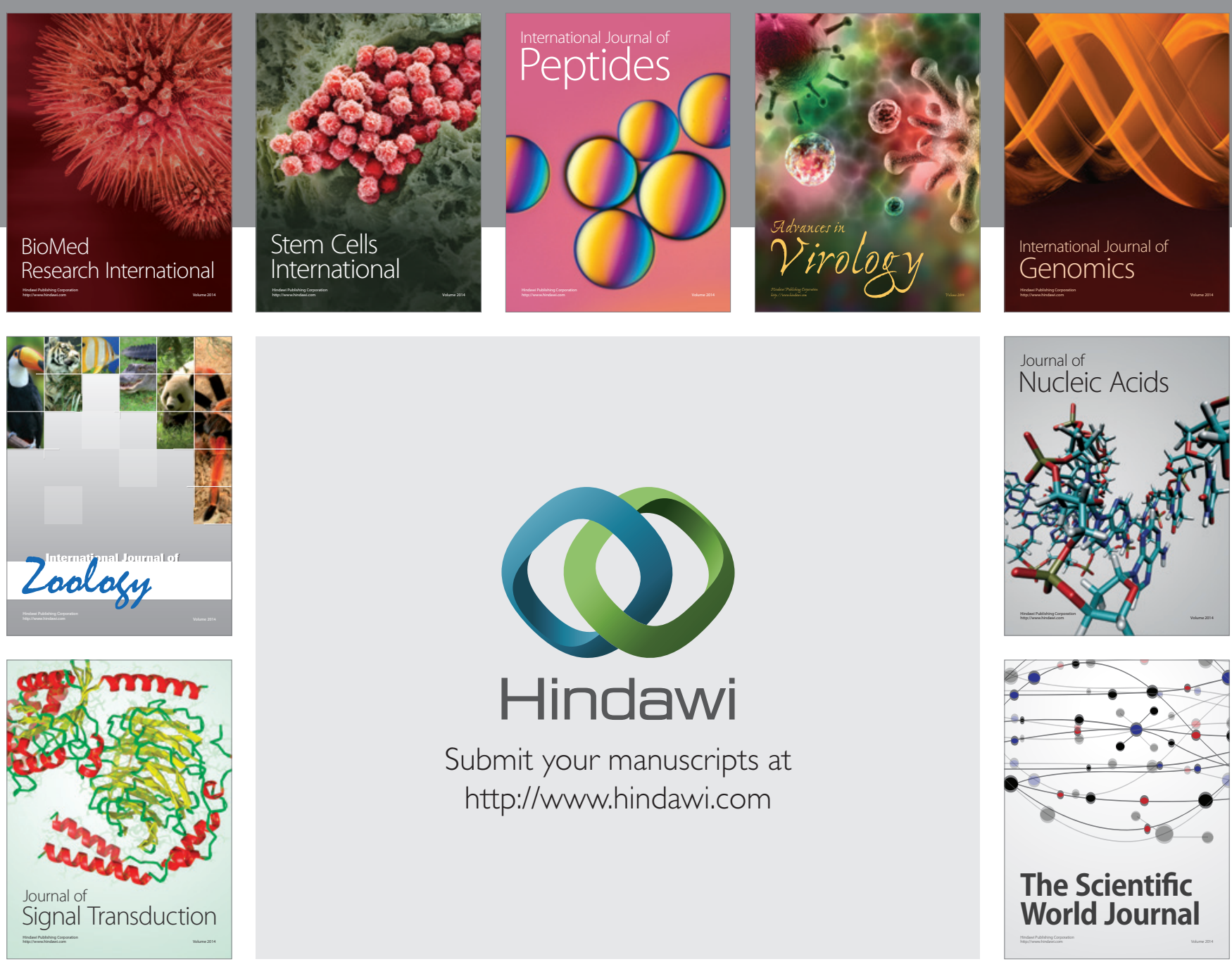

Submit your manuscripts at

http://www.hindawi.com
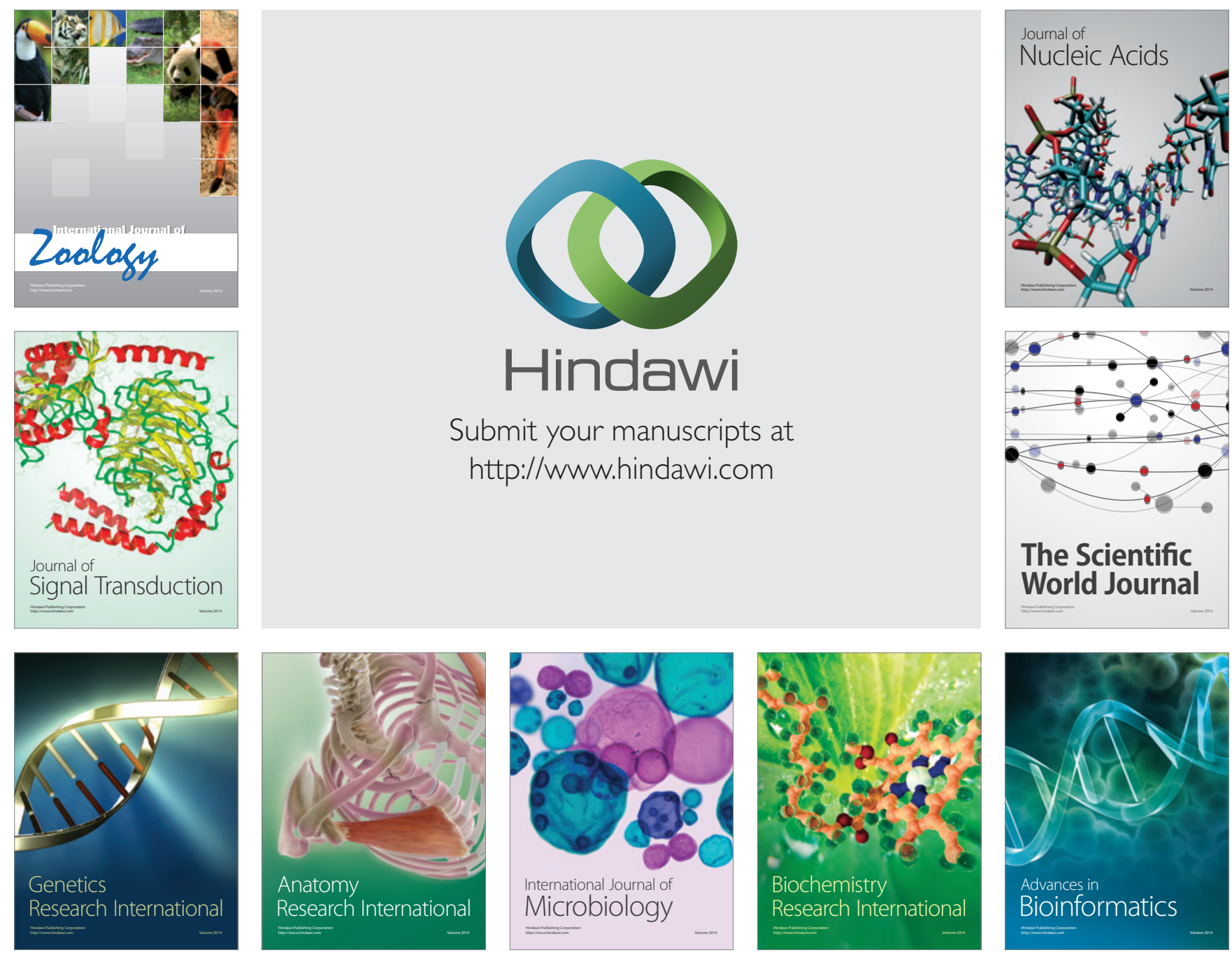

The Scientific World Journal
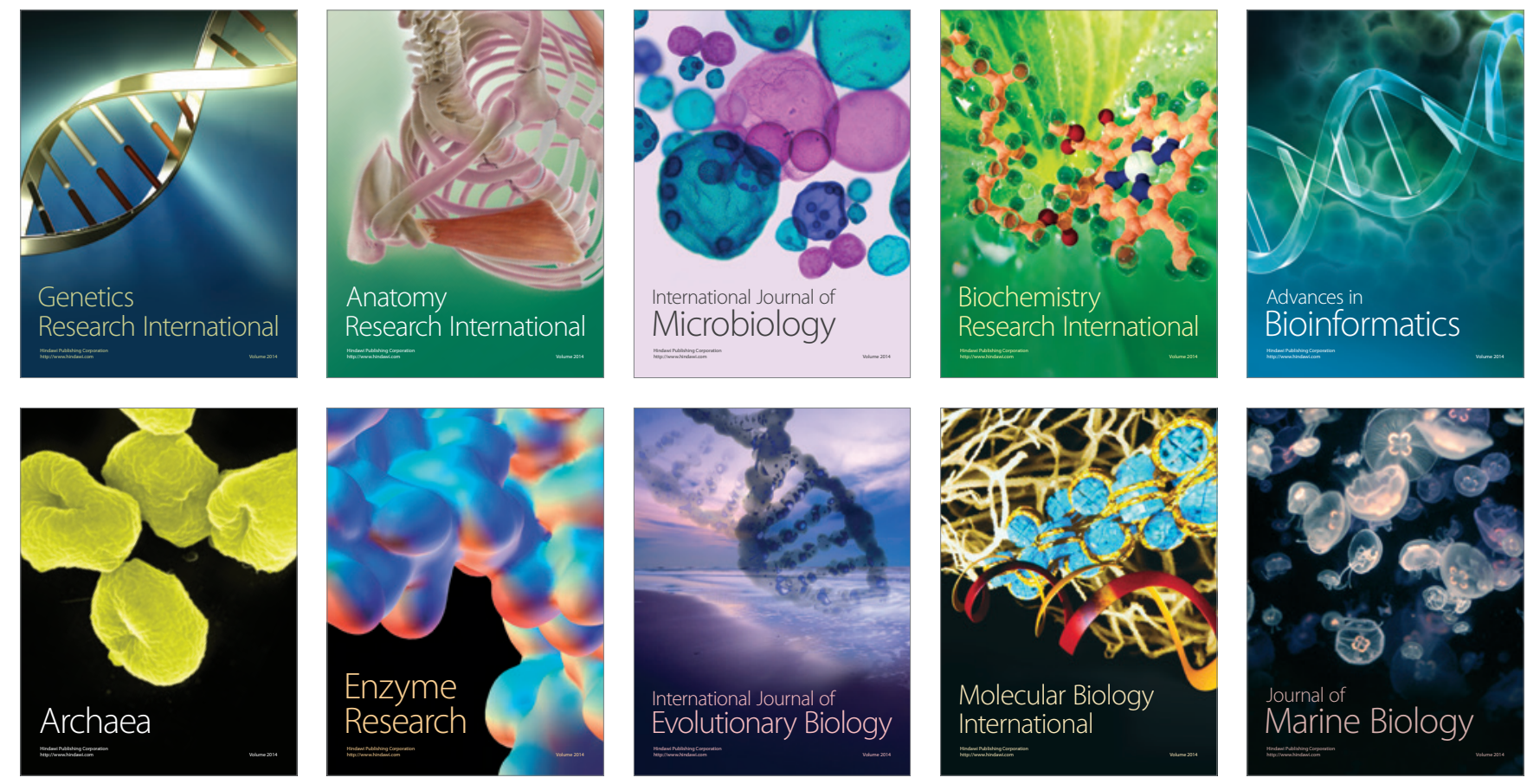